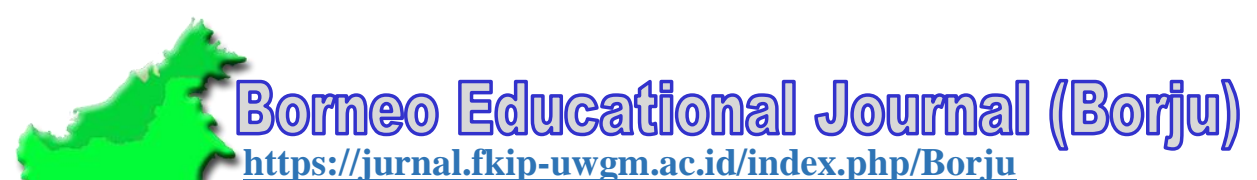

https://jurnal.fkip-uwgm.ac.id/index.php/Borju

E-ISSN: 2655-9323

February 2020, Vol. 02 No. 01

\title{
Teacher's Challenges in Teaching English to Young Learner using Montessori Method
}

\section{Chong Kai Jian', Widi Syahtia Pane ${ }^{2}$}

Universitas Widya Gama Mahakam, Indonesia ${ }^{1,2}$

Email Correspondence: chongkaijian3245@gmail.com

\begin{abstract}
Montessori Method is rarely used in Indonesia, especially Samarinda, and schools that apply this method are still relatively few. Teachers who choose this method and teach in schools that use this method are ready to face the challenges based on Pertiwi et al. (2020) when teaching children to learn English using a specific Method. This article reports a qualitative study that figures out the Teacher's challenges in teaching English for young learners around 5-6 years old using Montessori Method to "Follow the child" and use the English Language as their instruction language. Two kindergarten English teachers in Nido Montessori School participated in this study, and data were collected through interview-based on case study design.

This study indicated that teachers face several challenges when teaching English to young learners using the Montessori Method. Children who lack the English Language create limited communication between teachers and children because children can express what they need using the Language. Children with different characteristics challenges teachers focus on each of them and follow all of their need. Teaching English to the young learner using Montessori Method sometimes does not match the teaching topic or lesson, and this challenging Teacher to quickly use another teaching technique to make all the children able to follow the lesson.

In conclusion, teaching English to young learners using a specific method (Montessori Method) will challenge the English Teacher.
\end{abstract}

Keywords: Teacher's challenges; Young learner; Teaching English; Montessori Method

\begin{tabular}{|c|c|c|}
\hline DOI & : & https://doi.org/10.24903/bej.v2i1.621 \\
\hline Received & : & January 2020 \\
\hline Accepted & : & January 2020 \\
\hline Published & : & February 2020 \\
\hline $\begin{array}{l}\text { Copyright and } \\
\text { License }\end{array}$ & : & $\begin{array}{l}\text { Authors retain copyright and grant the journal right of first publication with the } \\
\text { work simultaneously licensed under a Creative Commons Attribution } \mathbf{4 . 0} \\
\text { International License that allows others to share the work with an acknowledgment of } \\
\text { the work's authorship and initial publication in this journal. } \\
\text { CC }\end{array}$ \\
\hline
\end{tabular}




\section{INTRODUCTION}

Montessori Method is an education program that is established spontaneously and aimed to provide children the opportunity to improve themselves and have freedom of movement and activity in a prepared environment [1]. Montessori Method also stands firm with it is philosophy of "follow the child." Dr. Maria Montessori is convinced that the Teacher should target the young learner as an individual instead of on the daily lesson plans. Although the Montessori kindergarten teacher plans daily lessons for every young learner, teachers must be alert of changes within the child's progress, interest, behavior, and mood.

Montessori Method is rarely used in Indonesia, especially Samarinda, and schools that apply this method are still relatively few. Teachers who choose this method and teach in schools that use this method are ready to face the challenges faced when teaching children to learn English using the Montessori Method. Furthermore, Maria Montessori argues that Montessori teachers and educators should have prepared mental, emotional, and even spiritual forms before plunging into Montessori education because they will face several difficulties in teaching. Due to this term, teachers and educators who have this preparation will be confronted with children's behavior, differing and even contradictory social beliefs, rules, and identities from the greater social community. These experiences can be challenging for both novice and veteran Montessori English teachers, especially in teaching English to young learners even though they have mastered all Montessori teaching material.

There are several challenges in teaching English to the young learner using a particular method. Based on [2], English teachers will face some general challenges: children lack English language skills, children have different characteristics, and monotonous learning uses the same method. In terms of children lack of English language skill that is because of mother tongue interference. [3] If teachers and students often use their native Language in daily communication, it will affect their target language. However, in the book of [4] Montessori Method must use English as Language of instructions.

Teachers should speak English in their communication with young learner even to the children that lack in English language. Due to this case, children will afraid to convey their need. This will challenge the Teacher to follow children's needs based on Montessori philosophy when students hard to speak in English and express their desire. Foreign Language brings difficulty to young learner because of the intonation, stress and pronunciation, [5]. Children feel hard to communicate with the Teacher using foreign Language and this will make 
a problem for the Teacher who uses certain teaching methods that require English Language as Language of instructions.

Children different characteristics also challenge Teacher in teaching English to young learner using Montessori Method. Teachers feel challenging to handle young learners with different characteristics [2]. Young learners with various characteristics required Teacher more pay attention to recognize children personalities. However, large amount of young learners in the classroom make teachers overwhelmed to focus on each children. Teacher will do presentation before children play with Montessori material, Teacher will shows step by step demonstration of the activity, (Montessori classroom guide, 2014) at this moment, Teacher will face challenge because several children will not keep quiet listen to Teacher but excited to touch the material and distract Teacher's presentation.

Furthermore, Teaching English to the young learner using a certain method provides a problem to Teacher. Same teaching method all the times makes teachers difficult to match it with the teaching topics and sometimes less attracted young learners in learning English. [2] "Toddler or kindergarten children should not be officially tested and graded because they can commonly assess as to understanding and production". [6] states that play are a device for different types of learning (such as learning about their world, achieving social competence, developed knowledge in various subject areas).

Playing creates the ideal learning conditions when the method and environment focus on the children's interests and developmental levels. Montessori Method provide designated teaching material which is look likes children toys. Teaching approach using toys or objects will attract children to the playing activities and in the same time achieve exploring experience. However, teaching young learners using objects and play with the objects will distract their attention to listen Teacher's instruction because according to [7] "people usually cannot give their full attention to two activities when they multitask".

Studies have indicated that Teacher face several challenges when teaching English to young learner in preschool and kindergarten level. Research by [8] shows the participants' views about the challenges while supporting the preschool learners acquiring English as Language of Learning and Teaching. Teachers are deeply worried that learners cannot express their emotions, Teachers fail to understand the pronunciation of English foreign language learners, Teachers difficult to get the messages they attempt to convey. This proved that children lack of English language skill will create challenge for English teacher to communicate with the children. 
Another study also proved that Teacher face several challenges when teaching English to young learner using Montessori Method. Research by [9] shows the objective of the study to find out Teacher's challenges based on being a Montessori Teacher and gives better understanding about the experience of a Montessori teacher in a leadership role. The result of the study shows the research subject; Claire, Montessori teacher, uses four different Discourses: Day-to-Day Teaching, Montessori, Social Reform and Personal Worth, in her teaching approaches. Several of challenges or dilemma also faced by the research subject such as the Marketization Discourse and Claire's internalized Montessori Discourse, comprising an impassioned knowledge (that mixed ages benefits development) and belief system (that mixed ages is socially correct).

Therefore, a study on find out Teacher's challenges in teaching young learners acquiring English Language using Montessori Method has been conducted. Study starts with mini observation to explore kindergarten teachers' challenges, who taught at the beginning of this school was opened. Researcher had found out teachers in Nido Montessori was provided with Montessori teaching material before becoming a Montessori teacher by Montessori educator. However, knowing Montessori teaching material was not enough if they does not experiences the teaching process by themselves. Therefore, researcher take this study to observe Teacher's challenges in teaching English to young learners using Montessori method based on their experiences in Nido Montessori School.

\section{METHODOLOGY}

This study is qualitative because intends to find out and explore Teacher's challenges in teaching English to young learner which bring some problems in smooth teaching [10]. Case studies is a research design which more focus to explore deep process of event or activity [10]. Researcher take case studies as the research design because it is the most appropriate design to find out teachers' challenges in teaching English to young learners using Montessori Method.

The researcher has been conduct this study in designated place because this study using phone call interview which means researcher were not conduct this study in natural field setting such as school, classroom and research locations. The designated place was a suitable and quiet place for researcher to do interview via phone call. Each participant has been interviewed on line and both interviewer and interviewee had prepared themselves in an isolated and quiet environment, free from as many distractions as possible. Participants have been interviewed individually and information, responses, and observations from other participants were not shared. 
Researcher chooses kindergarten teacher as research subjects because they have face more challenges to teach kindergarten children (5-6 years old) which those children have pass their golden age and Teacher's role to guide them get influence in English language. Children in this ages have to prepare themselves to get into elementary school for the next year, therefore kindergarten teacher have to put more effort in teaching kindergarten children for language development. The chosen research subjects has the same education level and teach the same class in Kindergarten class at Nido Montessori School. Participants has represents and fit the profile of the people that researcher need to reach based on [11]. Therefore, this study does not need statiscally representative of the greater population at hand because the samples are qualitatively generalizable.

In the study of qualitative research, researcher as the primary instrument in collecting data by interview (Guba and Lincoln 1981; Merriam 2002). Qualitative researcher are the one who gather the information in collecting data by using an instrument [12]. The role that researcher undertook while exploring Teacher's challenges in teaching English to young learners using Montessori Method is as Telephone-researcher (Interviews by phone call). Researcher will make a phone call to interviewee and ask several of questions that will help to answer the research questions in chapter one. Researcher will ask some questions that include Teacher's challenges in teaching English to young learners using Montessori method. In addition, Researcher also tap a record during the interview session to help researcher in collecting research data.

For this study, Researcher use semi-structured interview (Telephone-Researcher) to find out Teacher's challenges in teaching English to young learners using Montessori method (Rubin \& Rubin, 2012). The interview is via phone call to get more in-depth information and comfortable to interview participants who are hesitant to speak face to face. Data collecting procedure based on following steps:

1. Researcher started the interview using open-ended questions based on interview guideline

2. Researcher interviews the kindergarten teachers that teach English Language using Montessori method

3. Researcher taking notes during the interview session

4. Researcher tap audio recording during the interview session 
The analysis of interview results was carried out through [13] data analysis. In the process of reduction, the researcher will collect all informations from interview results, and audio recording of interview session via phone call then transform them by the process of selecting, focusing,simplifying and minimized them to complete the purpose of the research. Next in the process of data display, researcher displaying data in narrative text, therefore the result will be presented in descriptive. Lastly, researcher conclude data based on the theory and strengthened with data and detail information from the analysis of interview and recording of video as well. Researcher will revisiting the data at many times and do cross-check to verify the conclusions. Then, researcher discribing the conclusion of the study.

\section{FINDINGS}

Teacher's challenges in teaching English to young learner using Montessori method in this study were obtained from interview. This section presents 7 questions in semi structured interviews to answer research question in this study.

\subsection{Lexicon How long have you been as a kindergarten teacher in Nido Montessori} School?

Teacher A: I have been teaching in Nido Montessori Schoolfor three years but this new year semester is gonna be my fourth year.

Teacher B: I have been teaching for 2 years at Nido Montessori School.

This statement showed that both of the kindergarten teachers (Teacher A and Teacher B) are an experienced teacher in Nido Montessori School because Nido Montessori School was built and opened in 2017. In this year 2020, Nido Montessori School has been opened for almost four years. Experienced teachers certainly have already gone through many challenges in teaching English to young learners.

\subsection{What interested you in becoming a Montessori kindergarten teacher?}

Teacher A: The method. I really like Montessori method that maybe I will, I can apply in to my future to my kids and also I like the another teaching technique this school have such as Jolly Phonics like that, the thing that I never learned before.

Teacher B: That makes me interested in teaching at Montessori school because in Montessori has a philosophy that children are like keys, we must follow children so we must follow children what they want. Montessori is also organized, so it must be 
according to the rules from 0 , for example, if there is an apple tree, there is no way that tree will produce papaya, definitely an apple. So we must follow the rules.

Based on the statements above, both of the teachers interested with Montessori Method because of its philosophy and ideas in Montessori. Montessori surely using Jolly phonics technique to teach English sound and being combines with Montessori materials. Montessori philosophy which required Teacher to follow children needs, abilities and characteristics also interested Teacher B to be a Montessori Kindergarten teacher.

\subsection{What are the challenges teaching English to Kindergarten Learners using}

\section{Montessori Method?}

Teacher A: The challenge is when I have to face the kids that they never know English before which means they never speak English at home with parents so I have to introduce them from the very basic until they can all of the English.

Teacher B: There must be a lot of challenges. The first is certainly many children who do not know English. They know their native Language, Indonesian. That was the first challenge. The second challenge, same as I mentioned earlier, Montessori we have to follow the child so not all children are the same. We can't have a mindset if the kids are all the same. they are all different have different abilities and other challenges because in Montessori these mostly have toys so maybe they are less focused on the lesson but more focused on the toy or the material of the learning.

The statements above showed Teacher A and Teacher B have same challenges in teaching English to young learners that speak English as foreign Language. They have to teach the children that never speak English before from the very basic until they can understand English because the Language of Montessori is English. Children have to mastering English in order to understand instructions. Teacher B also mentioned that the second challenge was when teaching children with different characteristics and abilities but in the same time must to follow Montessori philosophy "Children should have freedom". Another challenges, Montessori classroom surrounded by Montessori materials which is like a toys for children and Teacher need to teach English using all those materials. When Teacher B explained about the English lesson, not all of children pay attention to her but keep distract by the Montessori materials.

\subsection{Why do you think the challenges happened?}

Teacher A: The challenge happened because it is a young learner. Maybe this school will be their first experience to study, especially study English with Montessori Method 
and also maybe this will be their first time to see the Montessori material to play them as it at home. So I need to introduce them the Montessori Method with English which they never speak English before and also I will be their first person that they will see in the school.

Teacher B: Because all children have different abilities, for example, if I want to teach this material, other children may not able to follow because of many different characters from them, so that includes challenges that are quite challenging to me. Another example if I want to teach current lesson but some of them not able to follow so my material would be delayed.

Based on Teacher A and Teacher B utterances, they think the challenge happened because they have to face young learners or children that still have not much experience about school and maybe Nido Montessori School was their first school and their Teacher was a first person they see in the school. Teacher A mentioned that not all the young learners familiar with English Language, so teacher A have to slowly introduce Montessori material using English language. Teacher B thinks the challenge happened because every children have different characteristics and abilities, when some children not able to catch up the lesson that been taught, Teacher B need to slowly teach them and make the current lesson delayed or incomplete being teach.

\subsection{What did you do when you face the challenges? How did it worked? Is it success or}

\section{failed? Why?}

Teacher A: It challenged myself to do extra effort and extra patience to teach them with all the best I can do for them. Not failed, I can say it worked, but it needs time. we cannot do that with only for one day or one week, so minimum I have to do that for one month and It can work for them.

Teacher B: So maybe we should know their knowledge first by approaching them. We ask first, we teach the easier first. We can also find other ways to take the attention of them, the child, or we can also find other ways that are more fun to teach the material that we want to teach so that children are interested in listening to us. For example we have to read books like Reading fairy tales or we can use materials like "The Moveable Alphabet". so not only in written form. So if for example they are not interested, we look for other ways that are more interesting so they want. Yes it success because they are 
interested and they are not bored, they want to listen, they want to interact and want to give feedback. When we ask they want to answer.

From the illustration above, Teacher A handle or face the challenges with socialemotions which is put more effort and more patience. Teacher A also said keep put extra effort and extra patience to teach children minimum in one month to make them understand Teacher's instructions. Teacher A state this action are success because it is work for young learners. Teacher B face the challenges with step by step, first approaching them or build good relationship with those children, second, ask what the children needs, teach a very simple lesson. Next, find out another ways to attract children attention in terms of reading, for example read books sounds like read storybooks to make children listen to Teacher. When Teacher have to teach vocabulary not only use written alphabet but use Montessori materials such as "The Moveable alphabet". Teacher A said these actions are success because after applying those steps children manage to listens to Teacher, keep interacts and give feedback when Teacher asked.

\subsection{Can you describe how the situation in the classroom when you face the challenges?}

Teacher A: The first thing that I always face is the condition is when the kids cannot sit properly, can't listen us properly because they just want to play and they will see the Montessori material as a toys but actually I need to tell them how to do it properly. So that is almost happen every day. They always want to touch the materials before I introduce how to do that.

Teacher B: For example I explained about how to read one sentence in three words in English. For example there are ten children, seven children who are able and able to follow but the remaining three children are unable to follow or they are not focused. So I as a facilitator I can invite them for example to sing or read one sentence by means of the "phonics" movement. So they are all can follow.

Based on illustration above, teaching children using Montessori method sometimes will distract children attention because Montessori materials looks like a toys for children until make them very interest to touch those material either than listen to the instructions or lesson that Teacher should delivered. Besides, as an English teacher to teach ten young learners in a class is not an easy. Not all ten children capable to follow the Teacher, when Teacher have to teach vocabulary, Teacher need to perform "phonics" movement to ease children receive the lesson. 


\subsection{What are some challenges that you did not anticipate while being a kindergarten}

\section{teacher?}

Teacher A: I think it is the kid's mood because the kids' moods will always changing every time. So it will be the big challenge for me while I have to teach them all. For example in one class I have ten kids, but sometimes there must be one or two kids that doesn't want to listen or doesn't want to study and crying.

Teacher B: Certainly when a child has a small accident such as falling or nudged by a friend, there is a friend who causes injury, and other conditions may be children fighting over toys, when a friend has played with one toy, another friend also wants the same toy. So it is a challenge that cannot be anticipated.

Utterances above showed kindergarten teacher will face some challenges that happened without Teacher's expectations. Young learners' characters or mood always change over time, when children in a bad mood, children will not listen and did not interested to study. Furthermore, small accident that happen in a school such as children fighting over toys (Montessori materials) also challenged Teacher because that conditions able make lesson time not work smoothly.

\section{DISCUSSION}

\subsection{Lack of English Language Skills}

Teacher $\mathrm{A}$ and Teacher B argued that not every Kindergarten children in Nido Montessori School speaks English in their home. Several of children did not familiar with English Language because they speak Indonesia language or their mother tongue language. They learn English at school. Their main Teacher as their English Teacher was the first person they will meet at school. Teacher feels challenging to communicate with them and to teach them from the very basic of English or introduced them Montessori materials using English language [14]. Furthermore, Montessori Method apply English language as the Language of instructions. Teachers have to speak in English to communicate with children and to follow Montessori principle.

\subsection{Different Characteristics}

There are 10 children in each classroom, not all of the children have a same characteristics and abilities. Teacher have prepared all of lesson material but sometimes the lesson will not completely delivered because get distracted of children's mood, children's needs, children's focus and certain situations such as children fighting over Montessori materials. 
Based on Montessori philosophy, Teacher has to follow children. This challenge teacher to teach English using Montessori Method because Teacher are having problems to complete their teaching materials and follow each children's needs. In the book of Montessori Classroom Guide by [4] explained Montessori principle to "follow the child". Teachers must be aware to changes in the child's interest, mood, progress and behavior.

However, according to [2] Young learners with various characteristics required Teacher more pay attention to recognize children personalities. Large amount of young learners in the classroom make teachers overwhelmed to focus on each children. Teacher A and Teacher B argued that they have to follow the child based on Montessori philosophy but ten children with different characteristics challenged them to focus on each children and complete the teaching lesson.

\subsection{Teaching Method}

Montessori classroom surrounded by Montessori materials which will be used for children's learning tools. Teacher will display and introduced the certain Montessori Materials to children using English language. However, Teacher A argued that children always get distracted with the materials, children often touch all the materials before Teacher explain how to play and learn with the materials, children lost their attention to the lesson when face Montessori materials. Teacher A emphasize that this situation almost happen every school day. In addition, teaching new vocabularies to children using Montessori material not always accomplished to children that not capable in English language. Teacher B stated that sometimes Teacher need to use "phonics" movement to teach vocabularies or sentences. Then, those children will follow the action and sounds.

Based on [2], another challenges that Teacher faced in teaching English for certain method is same teaching method all the times makes teachers difficult to match it with the teaching topics and sometimes less attracted young learners in learning English. Teacher B argued that when teach English vocabularies using Montessori method, not all the children capable to follow Teacher, Teacher need to use "phonics" movement to make all the children follow Teacher to remember the vocabularies. Due to this terms, Teacher were facing challenges when teach vocabularies using Montessori Method because it is not match to the teaching lesson.

Furthermore [6] states that play are a device for different ways of learning (such as learning about their world, achieving social competence, expands knowledge in various subject areas). However, teaching young learners using objects and play with the objects will distract 
their attention to listen Teacher's instruction because according to (Just et al. 2001) people often difficult give their full attention to two activities when they multitask. Teacher A stated that young learners difficult to give their attention when Teacher are explain about the lesson because they looks Montessori materials as a toys. When Teacher present the materials while playing with the materials, young learners are not able to focus with Teacher's instruction but keep distract Teacher with touching to the materials.

\section{CONCLUSION}

Conclusion, Teacher's challenges in teaching English to young learners were come from lack of English language skills, different characteristics, and teaching method. Teacher faced the challenge when teach English to children that lack in English language skills because young learners not speak English at home and usually use Indonesia language as their communicating Language. Children with different characteristics make Teacher face the challenge to focus on each of them and follow their needs. Teaching English to young learners using Montessori Method sometimes not match to the teaching topic or lesson and this challenge teacher to quickly use another teaching technique to make all the children able to follow the lesson.

\section{REFERENCES}

[1] M. Montessori, Basic Ideas of Montessori's Educational Theory (Clio Montessori). ABC- CLIO Ltd, 1997.

[2] R. S. Pertiwi, I. Salabiyati, D. Damara, B. Pratolo, and U. A. Dahlan, "The Teacher' s Perspectives About Challenges of Teaching English for Young Learners : A Case Study at English Course for Young Learners," vol. 397, no. Icliqe 2019, pp. 65-74, 2020.

[3] O. F. Fatiloro, "Tackling the challenges of teaching English language as second language (ESL) in Nigeria," IOSR J. Res. Method Educ., pp. 26-30, 2015.

[4] North American Montessori Center (NAMC), Montessori Classroom Guide. North America: Dale Gausman, 2014.

[5] I. A. Khan, "Challenges of teaching/learning English and management," Glob. J. Hum. Soc. Sci., vol. 11, pp. 68-79, 2011.

[6] O. N. Saracho, An Integrated Play-based Curriculum for Young Children. New York: Routledge, 2012.

[7] A. Suziedelyte, "The Effect of Multitasking on Children's Noncognitive Skills," in The Economics of Multitasking, New York: Springer, 2016, pp. 61-89. 
[8] S. du Plessis and B. Louw, "Challenges to preschool teachers in learner's acquisition of English as Language of Learning and Teaching," South African J. Educ., vol. 28, no. 1, pp. 53-74, 2008.

[9] O. Christensen, "Proving Montessori: Identity and Dilemmas in a Montessori teacher's lived experience," J. Montessori Res., vol. 2, no. 2, 2016.

[10] J. W. Creswell, Qualitative Inquiry and Research Design Choosing among Five Approaches, 3rd ed. London: SAGE Publication Ltd, 2013.

[11] J. W. Creswell, Educational Research. Boston: Pearson, 2012.

[12] J. Creswell, Research Design Qualitative, Quantitative, and Mixed Methods Approaches. United Kingdom: SAGE Publications, Inc, 2009.

[13] M. B. Milles, M. A. Huberman, and J. Saldana, Qualitative Data Analysis A methods Sourcebook Edition 3. 2014.

[14] F. Copland, S. Garton, and A. Burns, "Challenges in Teaching English to Young Learners: Global Perspectives and Local Realities," TESOL Q., vol. 48, no. 4, 2014. 